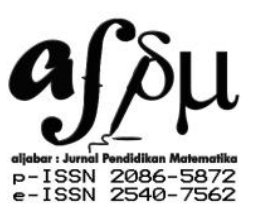

\title{
Pengembangan Modul Matematika Dengan Strategi Problem Solving untuk Mengukur Tingkat Kemampuan Berpikir Kreatif Matematis Siswa
}

\author{
Bambang Sri Anggoro \\ IAIN Raden Intan Lampung: bambang2802@yahoo.com \\ Submitted : 25-08-2015, Revised : 10-11-2015, Accepted : 16-12-2015
}

\begin{abstract}
This research is based on the low level of mathematical creative thinking ability of MAN 1 Pesisir Barat students and less optimal learning result, and there are still many teachers who apply conventional learning and also the weakness of the use of language in mathematics book and illustration which is not communicative and interactive so that does not succeed The core message of the book.Based on these issues, it is necessary to develop a mathematics learning that can provide flexibility of learners to learn to think actively and creatively in solving problems encountered, one of which learning by using modules.

This research was conducted with the aim to develop a mathematics module with strategic solving to measure the level of mathematical creative thinking ability of grade XI MA students on statistical materials. The research that the writer do is a module development research with several stages of product analysis phase that will be developed, initial product development stage, expert validation stage and test and revision phase, at revision stage that is to improve the module that has not met the module feasibility test standard, Ideas and suggestions from experts. In product trials, data collection is obtained by using test instruments with statistical materials, inscribed essay-form tests ability level of students' mathematical creative thinking.

Based on the results of research and data processing obtained the results of pre-test learning value with an average value of 20.0645, while the value of learning post-test has an average value of 39.6774, seen from the value known that there is an increase in student learning outcomes by the difference Class of 19,6129. So that the mathematics module with strategic problem solving with statistical material can measure the level of students' mathematical creative thinking ability.
\end{abstract}

Keywords: Creative; Mathematical; Module; Problem; Solving; Thinking

\begin{abstract}
Abstrak
Penelitian ini dilatar belakangi oleh rendahnya kemampuan tingkat berpikir kreatif matematis siswa MAN 1 Pesisir Barat dan hasil belajar yang kurang optimal, dan masih banyak guru yang menerapkan pembelajaran yang konvensional dan juga lemahnya penggunaan bahasa pada buku matematika serta ilustrasi yang tidak komunikatif dan interaktifsehingga tidak berhasil menyampaikan pesan inti buku.Berdasarkan permasalahan tersebut, maka perlu dikembangkan pembelajaran matematika yang dapat memberikan keleluasaan peserta didik untuk belajar berpikir secara aktif dan kreatif dalam memecahkan masalah yang dihadapi, salah satunya pembelajaran dengan menggunakan modul.
\end{abstract}


Penelitian ini dilakukan dengan tujuan untuk mengembangkan modul matematika dengan strategiproblem solvinguntuk mengukur tingkat kemampuan berpikir kreatif matematis siswa kelas XI MA pada materi statistika. Penelitian yang penulis lakukan merupakan penelitian pengembangan modul dengan beberapa tahap yaitu tahap analisis produk yang akan dikembangankan, tahap pengembangan produk awal, tahap validasi ahli dan tahap uji coba dan revisi, pada tahap revisi yaitu memperbaiki modul yang belum memenuhi standar uji kelayakan modul, sesuai dengan ide dan saran dari para ahli.Dalam uji coba produk, pengumpulan data diperoleh dengan menggunakan instrument tes dengan materi statistika, insrumen berbentuk essay tes kemampuan tingkat berpikir kreatif matematis siswa.

Berdasarkan hasil penelitian dan pengolahan data didapatkan hasil nilai belajar pretestdengan nilai rata-rata 20,0645, sedangkan nilai belajar post-test memiliki rata-rata nilai 39,6774 , dilihat dari nilai tersebut diketahui bahwa terdapat peningkatan hasil belajar siswa dengan selisih rata-rata kelas 19,6129. sehingga modul matematikadengan strategiproblemsolving dengan materi statistika dapat mengukur tingkat kemampuan berpikir kreatif matematis siswa.

Kata Kunci: Kreatif; Matematis; Modul; Problem; Solving.

\section{PENDAHULUAN}

Pendidikan sangat penting bagi setiap individu baik bagi kepentingan pribadi maupun dalam kedudukannya sebagai warga negara. Pendidikan berfungsi mengembangkan kemampuan dan membentuk watak serta peradaban bangsa yang bermartabat dalam rangka mencerdaskan kehidupan bangsa, bertujuan untuk berkembangnya potensi peserta didik agar menjadi manusia yang beriman dan bertakwa kepada Tuhan Yang Maha Esa, berakhlak mulia, sehat, berilmu, cakap, kreatif, mandiri, dan menjadi warga negara yang demokratis serta bertanggung jawab.

Pendidikan adalah kebutuhan hidup yang sangat penting bagi manusia, karena dengan pendidikan manusia dapat mengembangkan potensi yang ada pada dirinya melalui proses pembelajaran sehingga mampu memenuhi kebutuhan hidupnya. Secara garis besar tujuan pendidikan itu adalah untuk mengembangkan individu, baik jasmani maupun rohani secara optimal, agar mampu meningkatkan hidup dan kehidupan diri, kluarga, dan masyarakat. Pendidikan bukanlah sekedar membuat peserta didik menjadi sopan, taat, jujur, hormat, setia, sosial, dan sebagainya. Tidak juga bermaksud hanya membuat mereka tahu ilmu pengetahuan, teknologi, dan seni serta mampu mengembangkannya (Made, 2007).

Broom menyebutkan fungsi pendidikan sebagai transmini budaya, meningkatkan integrasi sosial atau bermasyarakat, mengadakan seleksi atau alokasi tenaga kerja melalui pendidikan itu sendiri, dan mengembangkan kepribadian. Pendidikan bukanlah sekedar membuat peserta didik menjadi sopan, taat, jujur, hormat, setia, sosial, dan sebagainya. Tidak juga bermaksud hanya membuat mereka tahu ilmu pengetahuan, teknologi, dan seni serta mampu mengembangkannya.

Dalam konteks islam pendidikan dan ilmu pengetahuan sangat dihargai, seperti dalam firman Allah SWT, dalam Qur'an Surat Ar-Ra'd ayat 11, yang berbunyi:

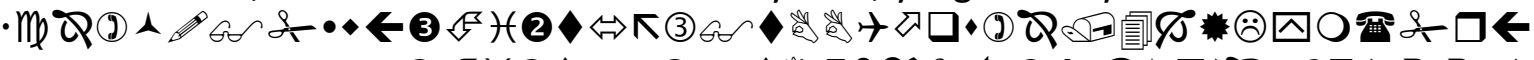

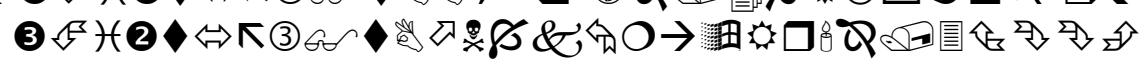




\section{Al-Jabar: Jurnal Pendidikan Matematika}

Vol. 6, No. 2, 2015, Hal 122 - 129

Artinya: "Sesungguhnya Allah tidak merubah keadaan sesuatu kaum sehingga mereka merubah keadaan yang ada pada diri mereka sendiri"

Berdasarkan ayat di atas, sejatinya seorang pendidik mempunyai usaha dalam mendidik peserta didiknya agar tercapai tujuan pendidikan. Dalam mengajar, pendidik harus mempunyai keterampilan yang baik agar materi-materi yang disampaikan dapat diterima dengan baik oleh peserta didik. Di sini tentu saja tugas pendidik adalah menciptakan suasana belajar mengajar yang menarik dan menyenangkan bagi semua peserta didiknya.

Program pendidikan melalui proses pembelajaran di sekolah sebagai lembaga pendidikan formal dipengaruhi oleh beberapa hal yaitu: peserta didik, kurikulum, tenaga kependidikan, biaya, sarana dan prasarana serta faktor lingkungan. Apabila hal tersebut dapat terpenuhi maka dapat memperlancar proses pembelajaran sehingga akan menunjang pencapaian hasil belajar yang maksimal yang pada akhirnya akan meningkatkan mutu pendidikan.Pada dasarnya tercapainya tujuan pembelajaran atau hasil pengajaran sangat dipengaruhi oleh tingkat kemampuan berpikir kreatif matematis siswa dalam memecahkan suatu masalah didalam proses belajar mengajar.

Matematika adalah disiplin ilmu yang telah dipelajari semenjak pendidikan dasar dan membantu perkembangan disiplin ilmu lain seperti fisika, kimia, biologi, ekomomi dan lainya. Dalam perkembangannya, banyak konsep matematika diperlukan untuk membantu menyelesaikan masalah dalam kehidupan sehari-hari yang dihadapi, seperti halnya untuk membantu manusia dalam memahami dan menguasai permasalahan sosial, ekonomi, dan alam. Dalam belajar metematika seseorang dilatih untuk berpikir kreatif, kritis, jujur dan dapat mengaplikasikan ilmu matematika dalam menyelesaikan suatu permasalahan dalam kehidupan sehari hari maupun dalam disiplin ilmu lainnya.

Sebelum melakukan penelitian, penulis terlebih dahulu melakukan pra-penelitian yang berguna untuk mengetahui gejala awal yang dihadapi oleh objek penelitian dan menghimpun data hasil belajar peserta didik yang telah ada. Bedasarkan wawancara penulis kepada salah satu guru matematika di Madrasah Aliyah Negeri (MAN) 1 Pesisir Barat, diperoleh keterangan bahwa masalah yang dihadapi guru adalah masih kurangnya kemampuan peserta didik dalam memecahkan masalah soal latihan matematika masih rendah, penyebab hal tersebut adalah dalam belajar matematika peserta didik cendrung menghafal rumus, meniru contoh soal yang diberikan oleh guru, dan kurangnya siswa dalam memahami materi sehingga tiap kali diberikan soal matematika yang berbeda, peserta didik belum mampu mengerjakan soal tersebut, akibatnya kemampuan peserta didik masih tergolong rendah meskipun peserta didik telah diberikan buku pegangan matematika. Hal yang senada juga terlihat bahwa kemampuan berpikir kreatif matematis siswa masih rendah, hanya ada beberapa orang siswa saja yang mempunyai kemampuan berpikir kreatif matematis, minimnya kemauan siswa untuk berpikir kreatif dalam memecahkan suatu masalah pada soal latihan matematika dan juga disebabkan oleh lemahnya penggunaan bahasa pada buku matematika serta ilustrasi yang tidak komunikatif dan interaktifsehingga tidak berhasil menyampaikan pesan inti buku, dengan kondisi buku seperti ini, sangat diragukan ketika buku ini digunakan tanpa dijelaskan dengan siswa, karena dikhawatirkan tidak akan tercapainya suatu tujuan dari pembelajaran tersebut. Mengingat masalah yang 
terjadi pada peserta didik, untuk mengurangi masalah yang ada, dalam proses belajar mengajar ia menggunakan metode ceramah, karena menurutnya metode ceramah akan lebih efesien dan mudah dipahami oleh peserta didik. la juga belum pernah mencoba strategi pembelajaran yang lain, karena mengingat lemahnya kemauan peserta didik dalam belajar memahami, memecahkan masalah dan juga berpikir kreatif matematis. la juga menyatakan bahwa belum pernah digunakan pembelajaran menggunakan modul.

Berdasarkan permasalahan tersebut, maka perlu dikembangkan pembelajaran matematika yang dapat memberikan keleluasaan peserta didik untuk belajar berpikir secara aktif dan mungkin dalam memecahkan masalah yang dihadapi, salah satunya pembelajaran dengan menggunakanmodul. Pembelajaran modul akan lebih efektif, efien dan relevan dibandingkan dengan pembelajaran dengan menggunakan metode ceramah yang cendrung bersifat klasikal dan dilaksanakan dengan tatap muka.

Dalam proses pembelajaran dengan menggunakan modul, siswa dituntut untuk belajar secara mandiri dan mampu memecahkan masalah dengan cara mengeluarkan ideide yang baru, karena peran guru hanya membagikan modul dan mengarah epada peserta didik, dan dengan dibagikan modul ini guru dapat melihat seberapa $\mathrm{j}_{\mathrm{i}}$ sserta didik mampu berpikir secara kreatif matematis dalam memecahkan masalah pada soal. Pembelajaran ini akan mempermudah peserta didik untuk memahami materi dan mencapai suatu tujuan yang diinginkan.

\section{METODE PENELITIAN}

Jenis penelitian yang digunakan dalam penelitian ini adalah penelitian dan pengembangan (research and development). Menurut Sugiyono, R\&D adalah metode penelitian yang digunakan untuk menghasilkan produk tertentu dan menguji keefektifan produk (Sugiyono, 2012:107). Produk yang akan dihasilkan dalam penelitian pengembangan tidak selalu berbentuk benda atau perangkat keras (hardware). Penelitian dan pengembangan yang dilakukan bertujuan untuk mengembangkan modul Matematika dengan strategiProblem Solving untuk mengukur tingkatkemampuan berpikir kreatif matematis siswa di Madrasah Aliyah Negeri (MAN) 1 Pesisir Barat.

Dalam penelitian ini, penulis menggunakan metode penelitian pengembangan Borg and Gall. Secara konseptual, pendekatan penelitian dan pengembangan mencakup 10 langkah umum, sebagaimana diuraikan Borg and Gall, seperti model dibawah ini (Sri, 2012):

1. Research and information collecting, termasuk dalam langkah ini antara lain studi literatur yang berkaitan dengan permasalahan yang dikaji, pengukuran kebutuhan, penelitian dalam skala kecil, dan persiapan untuk merumuskan kerangka kerja penelitian.

2. Planning, termasuk dalam langkah ini menyusun rencana penelitian yang meliputi merumuskan kecakapan dan keahlian yang berkaitan dengan permasalahan, menentukan tujuan yang akan dicapai pada setiap tahapan, desain atau langkah-langkah penelitian dan jika mungkin/diperlukan melaksanakan studi kelayakan secara terbatas.

3. Develop preliminary form of product, yaitu mengembangkan bentuk permulaan dari produk yang akan dihasilkan. Termasuk dalam langkah ini adalah persiapan komponen 
pendukung, menyiapkan pedoman dan buku petunjuk, dan melakukan evaluasi terhadap kelayakan alat-alat pendukung.

4. Preliminary field testing, yaitu melakukan ujicoba lapangan awal dalam skala terbatas, dengan jumlah 6-12 subyek. Pada langkah ini pengumpulan dan analisis data dapat dilakukan dengan cara wawancara, observasi atau angket

5. Main product revision, yaitu melakukan perbaikan terhadap produk awal yang dihasilkan berdasarkan hasil ujicoba awal. Perbaikan ini sangat mungkin dilakukan lebih dari satu kali, sesuai dengan hasil yang ditunjukkan dalam ujicoba terbatas, sehingga diperoleh draft produk (model) utama yang siap diuji coba lebih luas.

6. Main field testing, biasanya disebut uji coba utama yang melibatkan khalayak lebih luas.

7. Operational product revision, yaitu melakukan perbaikan/penyempurnaan terhadap hasil ujicoba lebih luas, sehingga produk yang dikembangkan sudah merupakan desain model operasional yang siap divalidasi.

8. Operational field testing, yaitu langkah uji validasi terhadap model operasional yang telah dihasilkan.

9. Final product revision, yaitu melakukan perbaikan akhir terhadap model yang dikembangkan guna menghasilkan produk akhir (final).

10. Dissemination and implementation, yaitu langkah menyebarluaskan produk/model yang dikembangkan kepada khalayak/masyarakat luas, terutama dalam kancah pendidi kan.

Tekhnik pengumpulan data dalam penelitian ini dilakukan dengan beberapa cara yaitu wawancara atau interview, Pre-Test dan Post-Test, observasi. Teknik analisis data dengan uji normalize gain:

$$
\mathrm{G}=\frac{S_{\text {post }- \text { test }}-S_{\text {pre }- \text { test }}}{S_{\text {maksimum }}-S_{\text {pre-test }}}
$$

Uji normalitas digunakan untuk menguji keabsahan sampel atau untuk mengetahui data tersebut berdistribusi normal atau tidak. Untuk menguji normalitas digunakan metode Lilifors, uji kesamaan variansi, dan uji hipotesis.

\section{HASIL PENELITIAN DAN PEMBAHASAN}

Penelitian ini dilakukan dengan beberapa tahapan, berikut hasil yang telah dilakukan: diantaranya bahwa analisis produk awal dilakukan dengan observasi terhadap beberapa buku yang dipakai disekolah dan wawancara terhadap guru matematika kelas XI. Hasil observasi dan wawancara adalah sebagai berikut: Buku yang dipakai disekolah sudah bervariasi namun belum digunakan pembelajaran menggunakan modul, produk yang dihasilkan dimungkinkan sangat membantu guru-guru matematika meningkatkan kemampuan berpikir kreatif matematis siswa dalam memecahkan masalah soal matematika, dan produk yang digunakan adalah modul pada bab materi statistika kelas XI MAN 1 Pesisir Barat.

Analisis produk awal dilakukan dengan observasi terhadap beberapa buku yang dipakai disekolah dan wawancara terhadap guru matematika kelas XI. Hasil observasi dan wawancara adalah sebagai berikut:

1. Buku yang dipakai disekolah sudah bervariasi namun belum digunakan pembelajaran menggunakan modul. 
2. Produk yang dihasilkan dimungkinkan sangat membantu guru-guru matematika meningkatkan kemampuan berpikir kreatif matematis siswa dalam memecahkan masalah soal matematika

3. Produk yang digunakan adalah modul pada bab materi statistika kelas XI MAN 1 Pesisir Barat.

Selain itu uji standar kelayakan. Standar kelayakan isi terdiri dari kesesuaian materi dengan standar kompetensi dan kompetensi dasar, keakuratan materi, kemutakhiran teori, mendorong keingin tahuan siswa, serta pengayaan. Standar kompetensi pada materi ini adalah menerapkan konsep statistika dalam pemecahan masalah. Sedangkan kompetensi dasar pada materi ada 4 yaitu mengidentifikasi data statistika, menentukan ukuran pemusatan data, menyajikan data dalam bentuk tabel dan diagram, menentukan ukuran penyebaran data. SK dan KD tersebut yang menjadi acuan dalam mengembangkan modul.

Kemudian kebahasaan. Kebahasaan dalam bahan ajar yang dikembangkan dilihat dari beberapa aspek yaitu harus sesuai dengan tingkat perkembangan intelektual peserta didik (pesan atau informasi disampaikan dengan bahasa yang menarik, lazim, dan sesuai dengan tingkat perkembangan kognitif peserta didik), mendorong peserta didik untuk berpikir kritis, dan penggunaan simbol matematika yang tepat.

Dalam proses mengembangkan produk ini, penulis mengumpulkan beberapa buku matematika yang selama ini digunakan di sekolahan maupun buku cetak lainnya. Dalam proses ini, penulis tidak serta merta merubah isi materi yang ada, namun menggabungkan materi dari beberapa sumber, dengan memperhatikan beberapa poin standar kelayakan modul yang terdiri dari standar kelayakan isi, standar kelayakan penyajian dan standar kelayakan kebahasaan.

Penelitian ini termasuk penelitian dan pengembangan (Research and development) yaitu penelitian yang berorientasi menghasilkan sebuah produk media dengan kualitas baik atau tidak untuk dapat digunakan sebagai sumber pembelajaran. Produk yang dikembangkan dalam penelitian ini berupa modul matematika dengan strategi problem solving strategiesuntuk mengukur tingkat berpikir kreatif matematis siswa pada mata pelajaran matematika di SMA/MA. Sumber belajar yang dikembangkan pada dasarnya adalah sumber pembelajaran dalam bentuk modul dengan strategi problem solving didalamnya. Penelitian ini dilakukan dengan beberapa tahap yaitu analisis data produk yang akan dikembangkan, mengembangkan produk awal, validasi ahli dan kemudian revisi.

Analisis produk yang dikembangkan dilakukan melalui wawancara terhadap guru matematika dengan tujuan untuk mengetahui buku apa saja yang selama ini dipakai di sekolahan serta tanggapan guru terhadap modul matematikadengan strategi problem solvinguntuk mengukur tingkat kemampuan berpikir kreatif siswa. Berdasarkan hasil wawancara yang dihasilkan, guru sangat apresiasi dan mendukung adanya modul matematika dengan materi statistika tersebut supaya penyampaian materi bisa dapat memudahkan peserta didik untuk lebih memahami isi materi statistika tersebut.

Tahap selanjutnya adalah pengembangan produk awal. Sebagai bahan acuan pengembangan produk adalah silabus pembelajaran buku yang dipakai di sekolah. Salah satu kesulitan dalam mengembangkan produk ini yaitu kurangnya kemampuan peniliti dalam membuat materi ajar, sehingga peneliti berkonsultasi pada ahli-ahli yang biasa menyusun materi yaitu kepada dosen-dosen matematika. 
Selanjutnya adalah validasi produk, yaitu uji kelayakan modul yang sudah dikembangkan. Penilaian terhadap moduldiberi standar layak atau tidak. Standar modul yang diberi tidak, bukan berarti tidak layak sama sekali, namun hanya ada yang perlu ditambah dalam modul yang dikembangkan. Beberapa poin pertimbangan yang belum memenuhi standar kelayakan modul, diantarnya yaitu kemutakhiran mteori, mendorong keingin tahuan siswa, penyajian, pengayaan dan kebahasaan. Hasil dari uji validasi ini yang nantinya akan dijadikan acuan untuk merevisi produk.

Proses revisi disesuaikan dengan hasil validasi ahli. Dari hasil validasi di atas, ada beberapa poin yang belum sesuai dengan keakuratan materi, kemutakhiran teori, mendorong keingintahuan, pengayaan, penyajian, dan kebahasaan.penimbang II dan penimbang IV memberikan kritik dan sarannya untuk setiap poin di atas yang belum memenuhi keakuratan materi, kemutakhiran teori, mendorong keingintahuan, pengayaan, penyajian dan kebahasaan modul, sehingga setelah direvisi tidak dilakukan uji validasi kembali.

Tahap selanjutnya dalah revisi produk yang telah melalui uji validasi. Revisi dilakukan pada bagian yang dianggap belum memenuhi kkalayakan modul sesuai dengan masukan yang diberikan oleh para ahli. Hasil yang telah direvisi ini yang akan menjadi produk modul matematikadengan strategi problem solving untuk mengukur tingkat kemampuan berpikir kreatif matematis siswa.

Tujuan akhir dari penelitian pengembangan ini adalah untuk mengetahui kelayakan dan efektivitas modul statistika dalam proses pembelajaran di MA pada salah satu kajian matematika materi statistika.

Untuk mengetahui tingkat kelayakan modul statistika maka dilakukan uji validasi dari ahli, dan terlebih dahulu dalam pembuatannya mendapatkan saran dan arahan dari pembimbing serta berdasarkan atas bidang keahlian yang dikuasai.

Pengembangan modul matematika tersebut dalam pengembangannya melalui beberapa tahap. Tahapan dalam pengembangan modul statistika dimulai dari analisa produk awal, mengembangkan produk awal, validasi ahli dan revisi, uji coba modul dan analisis. Berdasarkan hasil validasi dan uji coba produk diketahui bahwa dari hasil penilaian mengenai modul statistika memiliki kategori cukup bagus (layak) dan menarik untuk digunakan dalam proses belajar mengajar disekolah pada kelas XI.

Dari hasil belajar yang didapatkan peneliti bahwa terdapat peningkatan hasil belajar setelah diberi perlakuan dengan penggunaan modul statistika. Dimana sebelum diberi perlakuan dengan penggunaan modul statistika, hasil rata-rata nilai kelas XI IPA 1ialah 20,0645akan tetapi pada saat setelah diberi perlakuan berbeda dengan penggunaan modul statistika maka nilai hasil belajar kelas XI IPA 1 dengan rata-rata nilai39,6774Berdasarkan nilai tersebut diketahui bahwa terdapat peningkatan hasil belajar siswa, dengan selisih ratarata $19,6129$.

Dari data yang didapatkan terdapat selisih antara hasil belajar sebelum dan sesudah pemberian bahan ajar ini. Peningkatan hasil belajar seperti inilah yang meyakinkan peneliti bisa mengambil kesimpulan bahwa dengan penggunaan modul matematika dengan materi statistika dapat meningkatkan kemampuan berpikir kreatif matematis siswa. hasil belajar peserta didik, ini juga secara langsung dapat dikatakan bahwa penggunaan modul matematika statistika ini dapat meningkatkan kemampuan berpikir kreatif matematis siswa. 
Dikarenakan soal-soal yang dikerjakan oleh peserta didik merupakan soal-soal yang didalamnya terdapat indikator untuk meningkatkan kemampuan berpikir kreatif matematis siswa.

Klebihan dan kekurangan produk hasil pengembangan ini memiliki beberapa kelebihan antara lain:

1. Modul matematika dengan strategi problem solving dapat mengukur tingkat kemampuan berpikir kreatif matematis siswa.

2. Modul matematika dengan strategi problem solvingdapat membuat peserta didik lebih tertarik untuk mengikuti proses pembelajaran.

3. Modul ini dilengkapi dengan gambar, serta dicantumkan contoh dalam kehidupan sehari-hari sehingga peserta didik lebih mudah memahami isi materi yang terdapat dalam modul.

4. Dalam proses penelitian pengembangan ini masih banyak kekurangan dan keterbatasan peneliti, dalam hal kemampuan peneliti dalam membuat materi ajar,sehingga peneliti berkonsultasi pada ahli-ahli yang biasa menyusun materi seperti guru dan dosen.

\section{SIMPULAN DAN SARAN}

Berdasarkan pembahasan dan hasil pengembangan dalam proses yang dikembangkan oleh peneliti dalam penelitian pengembangan (research and developmen). Maka dapat disimpulkan bahwa dalam pengembangan modul Matematika dengan metode matematika dengan strategi problem solving untuk mengukur tingkat kemampuan berpikir kreatif matematis siswa sangat menarik dijadikan sebagai sumber belajar. Simpulan yang dapat diambil dari penelitian pengembangan ini adalah sebagai berikut:

1. Dengan menggunakan metode research and development telah dikembangkan produk berupa modul matematika dengan strategiproblem solving untuk kelas XI SMA/MA.

2. Modul ini dikembangkan melalui tahapan-tahapan penelitian yaitu, tahap analisis produk yang akan dikembangankan, tahap pengembangan produk awal, tahap validasi ahli dan tahap revisi.

3. Produk yang dihasilkan adalah modul matematika berupa modul matematika dengan strategi problem solving untuk SMA kelas XI semester ganjil pada materi statistika.

Modul matematika dengan materistatistika dengan strategi problem solving dapat mengukur tingkat kemampuan berpikir kreatif matematis siswa, karena dalam uji coba produk didapatkan hasil nilai belajar pre-testdengan nilai rata-rata 20,0645, sedangkan nilai belajar post-test memiliki rata-rata nilai 39,6774. Berdasarkan nilai tersebut diketahui bahwa terdapat peningkatan hasil belajar peserta didikdengan selisih rata-rata kelas 19,6129. sehingga modul matematika dengan strategi problemsolvingdapat mengukur tingkat kemampuan berpikir kreatif matematis siswa.

\section{DAFTAR PUSTAKA}

Made, P. (2007). Landasan Kependidikan. Jakarta: Rineka Cipta.

Made, W. (2014). Strategi Pembelajaran Inovatif Kontemporer. Jakarta: Bumi Aksara.

Mahmud. (2011). Pemikiran Pendidikan Islam. Bandung: Pustaka Setia, 2011.

Rama, Y. (2010). Metode Logi pendidikan agama Islam (Edisi Revisi). Padang: Kalam Mulia. 


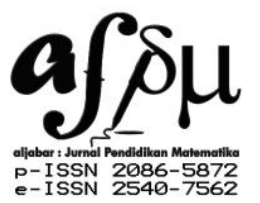

Al-Jabar: Jurnal Pendidikan Matematika Vol. 6, No. 2, 2015, Hal 122 - 129

Slameto. (2010). Belajar \& Fktor-faktor yang Mempengaruhi. Jakarta: Rineka Cipta.

Sudirman, N. (1991). Ilmu Pendidikan. Bandung: Remaja Rosda Karya.

Sugiyono. (2012). Metode Penelitian Pendidikan (Pendekatan Kuantitatif, Kualitatif dan $R \& D)$. Bandung: Alfabeta. 